\title{
Leader-Member Exchange in Different Organizational Cultures and Effects to Organizational Burnout
}

\author{
Erdem Kırkbeşoğlu \\ Başkent University \\ Faculty of Commercial Sciences, \\ Etimesgut, Ankara, Turkey \\ erdemk@baskent.edu.tr
}

\author{
Şule Tuzlukaya \\ Atılım Üniversity \\ Faculty of Management \\ İncek Gölbaşı, Ankara, Turkey \\ suletuzlukaya@atilim.edu.tr
}

\begin{abstract}
The purpose of this study is to examine the effect of leader-member exchange to burnout syndrome in different organizational cultures. Sample of the study is constituted by 183 participants who work in life insurance companies which represent organic organizational culture and non-life insurance companies which represent mechanical organizational culture. As a result of regression and correlation analysis, it is determined that leader-member exchange in organic organizational culture affects organizational culture negatively and in higher level compared to mechanical organizational cultures.
\end{abstract}

Keywords: Leader member exchange, organizational burnout and culture.

\section{Introduction}

In management and organization literature, leadership researches have been a subject of examination by behavioral movement. In this period, studies of leadership have begun with Traits Approach, continued with behavioral theories and contingency theories. When transactional and transformational leadership researches examined, within current approaches, leader-member exchange studies which discuss leader-group interaction has taken part in literature.

Since 1970s, both leader-member exchange and burnout issue has become a frequently discussed subject in literature. The main reason of this is that both variables have various results on both organization and employees. In many studies it was seen that worker turnover rate decreased; job satisfaction, extra role acting, productive and worker performance increased depending on leader-member exchange in high level (Dunegan et al. 1992, p. 60; Bauer and Green, 1996, p. 1539). On the other hand depending on burnout level, it is determined that various results have come up like over fatigue, sleeping problems, drop in energy, obsession, depression, decrease in selfesteem, lack of continuity, increase in intention of release and worker turnover rate, low productive and efficiency, decrease in performance, decrease in job satisfaction and 
loyalty to job and organization, disagreement with colleques, ignore clients and family members and not to pay attention to them (Maslach et al., 2001, p. 406).

There is no doubt it is important to have harmony and a perfect interaction between leader and employees in order to increase performance, provide productive and manage good relations. This harmony will also affect behaviors of employees and attitudes of them to organization. That employees are exposed to physical and psychological factors like poor management, economic troubles, negative physical conditions, conflicts of interest, personal problems, structure and system disorders can cause to employees unproductivity at work, lack of continuity and come up against various diseases (Albrect, 1988, sp. 50). The burnout which is a problem can cause to quit job by affecting employees health negatively both psychological and sociological, is accepted a situation needs to be prevent because it will bring heavy and serious results with it in terms of organization and individual.

Our aim in this study is to examine the effect of interaction between leader and employees to burnout syndrome in different organizational cultures. Because organizational culture consists of orders, rules and habits which determine how employees act, what is "normal", "acceptable", "natural" and "recognizable" (Kostera and Wicha 1996, p. 88). Therefore according to different organizational cultures, it is possible to come up different leader-member exchange or burnout symptoms.

\section{Theoretical Background}

\subsection{Organizational Culture and Leader-Member Exchange}

Culture notion has come up from studies which were done to present ethnic and national differences seen in various disciplines of social sciences (Hofstede, 1980; Ouchi, 1987). As each individual has a specific characteristic, each organization has a specific characteristic dividing it from others, too. Structural differences of organization make this culture distinct and separate it from others. Members in the organization begin to create organization climate and organizational culture which represent organization life by employees and including other structural forms and rules in time (Dipboye, Howell and Smith 1994).

According to Cameron and Quinn (1992), culture is basic values, beliefs, interpretations and approaches that describe an organization. Basic values and approaches related working process can become different even organizations in the same country and cause to raise organizational cultures. Frequently used definitions in literature are things that shared by members of organization, transferred each other and learnt by all members; include invisible elements and have common specifications like changing in time to adopt environment (Baumgartner, 2009; Schein, 1997). This created culture is a system shared by people in the same group and separates an organization from another. Differences shown reflect standards, stereotyped values, relations with other organizations and individuals by providing recognition in environment. Organizational culture affects the organizational behavior and performance more powerfully. Organizational culture control behaviors of member of organization through social norms, shared values, shared mental models and social identifications, therefore causes that members of organization think and act similarly by gathering for common aims. This effect reflects positively to performance of business. Also culture can affect individuals with authority to take administrative decisions, admin leader's leadership style and human resources management applications. All these factors affect 
performance of business in providing and using resources (Li, Lam and Qian 2001, p. 118). Organizational culture mostly begins with a leader or pioneer who puts forward specific ideas like vision, philosophy and business strategies and applies. When this ideas and values bring about to success, it institutionalizes and organizational culture which reflects visions and strategies of the pioneer or the leader comes up (Drucker 1992).

Long life businesses are businesses which have settled organizational culture. Settled organizational culture only requires agreement between leaders and other employees in the organization. How basic values and beliefs constitute core of organizational culture, the leader represents the power of culture symbolizes these values. Leaders are individuals in the most administration levels who contribute organizational culture, motivate employees, and represent organization and its culture against outside. All organizations have a culture good or bad, strong or weak. However, it is seen that organizations which can survive and outclass against rivals have a shared genuine culture.

In summary, there is a correlation between organizational culture and embracing this culture by employees. Organizations have to develop very sensitive and stable communication strategies in order to create a productive work environment and to increase workforce. In particular, the belief that the organization's norms and rules, the interaction between leaders and members is important to keep it healthy.

Leader-Member Exchange Theory's (LMX) importance results from presenting relationship-oriented approach to leadership. The leader-member exchange approach, the relationship evaluates the relationship between leader and follower together. Nowadays, the increase of the democratization process requires communicating with employees effectively, working together rather than managing them. This orientation also reflects in management theories, based on this theory put forward in the past years the approach also keeps validity today which both the leader and the follower have mutual interaction process.

Practical works related to leader-member exchange has been done since 1972 . Leader-member exchange has been developed firstly by Graen et al. (1982). Theory generally focuses on vertical relations between superiors and inferiors (Steiner, 1997, p. 60). Theory suggests that leaders in organizations cannot approach to all inferiors in the same leadership style due to limited time, resources and power (Wayne at all., 1994, p. 697).

LMX, the leader assumes that should be act to all subordinates in the same way rather than treating each hung with the different levels and forms of relationship and these relationships often mutual respect and trust based on the strong interactions occur as a result. According to this approach, leader classifies inferiors as "in-group" and "out-group ". Low LMX, while "out-group" relationships are formed of formal and normative relations, the high LMX, "in-group" relationships are based on mutual trust, mutual respect, mutual influence (Liu and Maslyn, 1998, p. 43). In-group relationships are on the basis of trust and respect and subordinate to the leader by paying more attention, support and resource distribution is concerned, the group members outside of such a trust will not have and organizational official connected to the control run (Breland et al., 2007, p. 3). For example, give more authority against leading members showed tolerance; members also heard strong commitment to business goals or show a 
high level of effort and performance (Bauer and Green, 1996, p. 1538). Non-group subordinates can perform much more routine and official relations with superiors to exchange input (Liu and Grace, 1980, p. 452). Leaders, subordinates outside the group, the official authority, rules and policies to evaluate the performance based on the lower support, confidence, and will reward comes. In contrast, the leader himself saw as close to the staff, staff with similar qualifications than positive evaluation, tend to rely more and more time to devote enters (Wayne, Shore and Liden, 1997).

However, the entire organizational structure of leader-member exchange in many studies that show similar results are expressed (Islam at all., 1994; Tzin at all., 2008; Jelena at all., 2012). Formative relationships between organizational culture and employee structure, with leaders will determine the nature of interaction between members. Therefore, members of different leaders in different organizational cultures are likely to interaction pattern.

For examining organizational structure contributing with studies of Cameron and Quinn (1992) of four different types of culture, is built in organizations argued. Cameron and Quinn (1992) with the typology based organizational culture at one end internal orientation at the other non-orientation where an axis at one end, the flexibility and dynamics at the other end stability and control that contains another axis cutting caused by the four different types can be seen. These four different cultures, human relations and development (clan) culture, bureaucracy (hierarchy) culture, market culture and adapt to the external environment (adhocracy) culture. In this study, our aim was to measure the impact on the organizational burnout by reference to the structural differences of organizational culture, leader - member exchange. Cameron and Quinn (1992) according to the typology of organizational culture are inherently bipolar. On the one hand the flexibility and participation, with an emphasis on "organic" culture of an organization (clan and adhocracy) on the other side control, order, balance and rationality, which emphasizes a "mechanical" organizational culture (hierarchy and market), is located (see Figure 1).

\subsection{Leader Member Exchange - Organizational Burnout}

The concept of burnout used by Freudenberger (1974) for the first time and as a result of excessive work of people does not meet the requirements of affairs come to a situation which means "emotional exhaustion" was characterized as a state. The most widely accepted definition of related burnout, belongs to Maslach (2003). To Maslach (2003, ss. 189) by exhaustion, stress in the workplace as a reaction against enhancer elements emerged in a long time is defined as a psychological syndrome. In this sense, Maslach and Jackson (1981) burnout of the person : (a) depersonalization (burnout interpersonal dimension represents and the person served or maintain his or together his people against the negative, solid, cynical, apathetic attitude development or they move away from state), (b) emotional exhaustion (burnout individually specify the size and emotional exhaustion (business considering the fatigue sensation and physical exhaustion (sleep reduction, chills, headache, pain to live) as manifested and (c) reduced personal accomplishment (a person's competence and a reduction in the feeling of accomplishment) defined as three dimensional cases have psychological syndromes. 


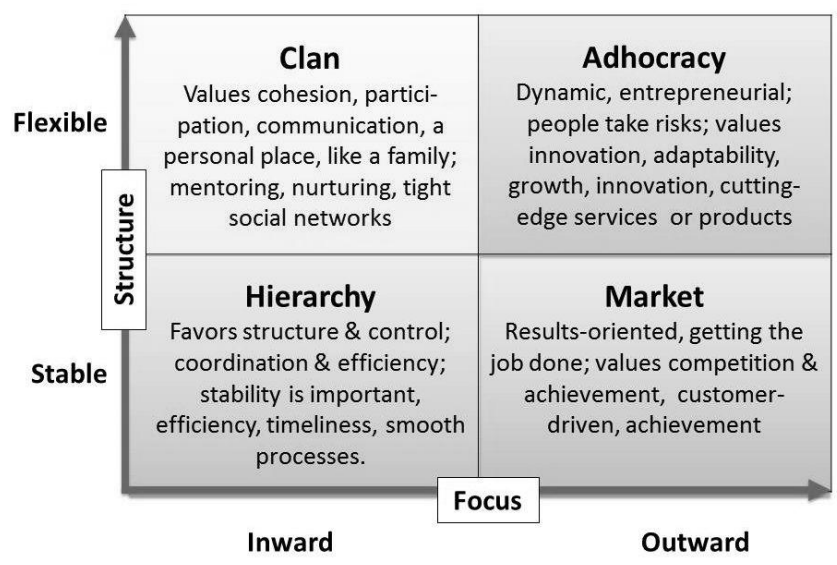

Figure 1: Competitive Values and Organizational Cultures

Sources: Cameron, K. S., Quinn, R. E. (1992). Diagnosing and changing organizational culture: Based on the competing values framework, Addison-Wesley, Reading, MA.

In terms of leader - member exchange when questioned organizational burnout, leading subordinates to offer support should be expected to vary depending on the level of burnout. That work-related demands are intense of the workload, but the job control (knowledge, skills, abilities, powers and access to resources) is lower in cases where individuals more stress lives and that of employees' depletion causes. Especially to the leaders of these people will suggest tasks that require extra effort and expect from them is clear that high performance. People cannot have the control necessary for job in fulfilling this task will fail. This will bring together burnout. Also at this point, is also important to support or not. As can be seen from the statement made earlier, leading to asthma in inner - group, beyond the formal employment contract provides social support and resources. In other words, the internal groups involved in subordinates social exchange in as a requirement of its leaders see more support, the decisions may participate, the more access to information is the organization, facilities, resources, career development and opportunities for advancement more than can benefit (Deluge and Perry , 1991, p. 239-240). In this case, the internal - developed high-quality relationship with the leaders of the group of employees' burnout likelihood of survival decrease. Also, in numerous studies (Seltzer and Numerof, 1988; McCain, 1994; Hetland et al. 2007), it has been found that the level of burnout can reduce depending on the leadership style.

In Turkey, there are structural differences of insurance companies depending on life insurance or non-life insurance. Kirkbesoglu and Tuzun (2009), in Turkey life insurance companies individualist, participatory and dynamic organizational culture that they have, on the other non-life insurance companies are more collective and stability oriented culture of an organization until they have stated. Adhering to these findings, life insurance companies Cameron and Quinn (1992) typology of organic organizational culture, organizational culture, the mechanical non-life insurance companies have said that. Therefore, participation and innovative actions is more important in organic organizational culture, organizational leader - member exchange will affect burnout less predictable. Mechanical organizational culture aimed at the more monotonous and continuity of a culture of organizational burnout due to leader - member exchange effects can be expected at a higher level. In this context, the following hypotheses can be developed: 
H1: Leader-member exchange in organic organizational culture affects organizational burnout in higher level and negatively with regard to mechanic organizational culture.

\section{Research Methodology}

\subsection{Method and Sampling}

In order to find answers to our hypothesis we carried out quantitative research and applied questionnaire as our method of data collection. Our questionnaire is designed for the purpose of measuring demographic and other types of variables. Research sample is constituted with 3 life insurance companies and 181 employees working in 4 non-life insurance companies have team-based organizational structure.

The questionnaire is applied to insurance companies both in İstanbul head offices and district offices in Ankara. Employees from each insurance company help us to make sure that the questionnaire has been filled out by respondents who are mainly responsible with insurance related tasks. The respondents were informed that we would keep the answers anonymous. Accordingly, we did not record their names on the questionnaire forms and we guaranteed that the data would be kept confidential and not be reached by the respondents' supervisors.

The valid questionnaires were identified after the questionnaire has been administered and collected. All analyses have been conducted though those who agreed to fill out a questionnaire. In the research, SPSS statistical program has been used for finding the frequency distributions. Afterwards, through our research hypothesis, the correlation analysis and multiple regression analysis are applied. The demographic information of the respondents can be seen below (Table 1).

Table 1: Demographic Information

\begin{tabular}{lrr}
\hline & $\begin{array}{c}\text { Organic } \\
\text { Organizational Culture }\end{array}$ & $\begin{array}{r}\text { Mechanic } \\
\text { Organizational Culture }\end{array}$ \\
\hline Sex & 60,6 & 59,2 \\
Female & 39,4 & 40,8 \\
Male & & \\
Age & & \\
$21-30$ & 23,6 & 25,8 \\
$31-40$ & 51,7 & 45,1 \\
$41-50$ & 15,0 & 17,2 \\
$51+$ & 9,7 & 11,9 \\
& & \\
Education & & 0,0 \\
Primary School & 0,0 & 7,0 \\
High School & 7,4 & 83,0 \\
Associate/Bachelor & 81,8 & 10,0 \\
Master/PhD & 10,8 & \\
& & 12,4 \\
Average Tenure (Year) & 7,2 & 28,3 \\
Avearage Employee Age & 24,9 & 98 \\
Sampling Size (person) & 83 & 4 \\
Sampling Size (company) & 3 & \\
\hline
\end{tabular}




\subsection{Questionnaire}

The questionnaire form of the research consists of three sections. In the first section, the form consists of questions to specify the demographic factors of the employees. The first section, the questionnaire the person, gender, age, education level, job title, work, unit, how long this business has been running and how long the supervisor is working with the determination has been attempted. In the second section of questionnaire, Leader-member exchange for Pellegrini and Scandura (2006) consists of 12 items; five-point Likert scale was used. As for the Maslach Burnout Inventory and Jackson (1981) and developed by and composed of 22 items rated on three subdimensions of burnout "Maslach Burnout Inventory" was used. SPSS 12.0 statistical data were analyzed by analysis software package.

\section{Findings}

In the first part of the study, data analysis and organizational leader-member exchange level reliability analysis is made of burnout levels. According to the results of reliability analysis $\alpha>0.60$ based on the value of the scales were found to have adequate reliability (see Table: 3 ).

In the first stage of data analysis, the difference between the mean values of leader-member exchange and organizational burnout of organizations with organic and mechanic organizational culture were tested. As a result of T-test, the average values related to burnout levels of organizations with organic culture and organizations with mechanic organizations has been found statistically differ from each other (table:2). On the other hand, there is no meaningful difference between their leader-membership exchange level averages.

Table 2: The Mean, Standard deviation and $t$ values of organizations with organic and mechanic organizational cultures

\begin{tabular}{|c|c|c|c|c|c|c|}
\hline & Organizations & Sample & Mean & St. Dev. & T values & $\mathbf{P}$ \\
\hline \multirow{2}{*}{$\begin{array}{l}\text { Leader } \\
\text { Member } \\
\text { Exchange }\end{array}$} & $\begin{array}{l}\text { Organic } \\
\text { Organizational Culture }\end{array}$ & 83 & 3,9 & 1,11 & \multirow[b]{2}{*}{2,67} & \multirow[b]{2}{*}{0,346} \\
\hline & $\begin{array}{l}\text { Mechanic } \\
\text { Organizational Culture }\end{array}$ & 98 & 3,8 & 0,98 & & \\
\hline \multirow{2}{*}{$\begin{array}{l}\text { Organizational } \\
\text { Burnout }\end{array}$} & $\begin{array}{l}\text { Organic } \\
\text { Organizational Culture }\end{array}$ & 83 & 3,0 & 0,88 & \multirow{2}{*}{3,21} & \multirow{2}{*}{0,076} \\
\hline & $\begin{array}{l}\text { Mechanic } \\
\text { Organizational Culture }\end{array}$ & 98 & 3,4 & 1,05 & & \\
\hline
\end{tabular}

In the following stage, in order to test the hypothesis the correlation analysis for the research variables of organizations with mechanic and organizations with organic organizational culture are conducted. Results also a leading member of both organizations in the culture of interaction and burnout are significant and show that there is a negative relationship. However, the strength of correlations in organic organizational culture $(\mathrm{r}=-.31, \mathrm{p}$-value $<0.01)$ compared to mechanical organizational culture $(r=-.24$, p-value $<0.01)$ is much more remarkable. 
E.Kırkbeşoğlu - Ş.Tuzlukaya 6/2 (2014) 26-36

Table 3: Correlation Analysis for Organic Organizational Culture

\begin{tabular}{lccccccccc}
\hline & Mean & SD & $\mathbf{1}$ & $\mathbf{2}$ & $\mathbf{3}$ & $\mathbf{4}$ & $\mathbf{5}$ & $\mathbf{6}$ & $\mathbf{7}$ \\
\hline 1. Gender & - & - & & & & & & & \\
2. Position & - & - & .19 & & & & & & \\
3. Age & 24.9 & 5.77 & .09 & $.24^{*}$ & & & & & \\
4. Tenure & 7,2 & 4.05 & .27 & $.16^{*}$ & $.11^{* *}$ & & & & \\
5. Education & - & - & .06 & .08 & .13 & .34 & & & \\
6. Leader Member Exchange & 3.9 & 1.11 & .19 & $.42^{* *}$ & .19 & $.16^{*}$ & .29 & $\mathbf{( . 6 9 )}$ & \\
7. Organizational Burnout & 3.0 & 0.88 & .12 & $-.22^{*}$ & $-.10^{*}$ & .26 & .31 & $-.35^{* *}$ & $\mathbf{( . 6 6 )}$ \\
\hline
\end{tabular}

Table 4: Correlation Analysis for Mechanic Organizational Culture

\begin{tabular}{lccccccccc}
\hline & Mean & SD & $\mathbf{1}$ & $\mathbf{2}$ & $\mathbf{3}$ & $\mathbf{4}$ & $\mathbf{5}$ & $\mathbf{6}$ & $\mathbf{7}$ \\
\hline 1. Gender & - & - & & & & & & & \\
2. Position & - & - & .48 & & & & & & \\
3. Age & 28.3 & 7.34 & .27 & $.36^{*}$ & & & & & \\
4. Tenure & 12.4 & 8.45 & .36 & $.07^{* *}$ & $.14^{*}$ & & & & \\
5. Education & - & - & .05 & .24 & .21 & .01 & & & \\
6. Leader Member Exchange & 3.8 & 0.98 & .28 & $.16^{*}$ & .11 & .23 & .19 & $(.70)$ & \\
7. Organizational Burnout & 3.4 & 1.05 & .12 & $-.17^{* *}$ & $-.29^{* *}$ & .08 & .01 & $-.24^{* *}$ & $(.72)$ \\
\hline
\end{tabular}

$* \mathrm{p}<0.05, * * \mathrm{p}<0.01$

In the next step leader-member exchange level to determine power hierarchical organizational burnout description made regression analysis, the results obtained are presented in Table 5. In regression analysis, demographic variables were entered as control variables in the first step, then, in the second step of leader-member exchange level for the culture of both organizations were included in the analysis. As can be seen from the table, a unit leader-member exchange level increases, the organizational burnout 0.482 for life insurance companies $(\beta)$ unit 0.281 for non-life insurance companies $(\beta)$ is decreasing unit. In addition, depletion of leader-member exchange on the level of the variance of $38 \%$ for life insurance companies, $25 \%$ for non-life insurance companies illustrate.

Table 5: Multiple Regression Analysis for Organizational Burnout

\begin{tabular}{|c|c|c|c|c|c|c|c|c|}
\hline & \multicolumn{4}{|c|}{$\begin{array}{c}\text { Organic Organizational } \\
\text { Culture }\end{array}$} & \multicolumn{4}{|c|}{$\begin{array}{c}\text { Mechanic Organizational } \\
\text { Culture }\end{array}$} \\
\hline & $\mathbf{N}$ & $\boldsymbol{\beta}$ & $\mathbf{R 2}$ & $\mathbf{F}$ & $\mathbf{N}$ & $\beta$ & $\mathbf{R 2}$ & $\mathbf{F}$ \\
\hline 1. Gender & & $0.205^{*}$ & & & & $0.124 *$ & & \\
\hline 2. Position & & $0.187 *$ & & & & $0.195^{*}$ & & \\
\hline 3. Age & & $-0.104^{* *}$ & & & & $-0.005^{* *}$ & & \\
\hline 4. Tenure & 85 & $-0.217^{*}$ & 0.38 & $53.14 * *$ & 98 & $-0.115^{* *}$ & 0.25 & $33.31 * *$ \\
\hline 5. Education & & $-0.009 *$ & & & & $0.052 *$ & & \\
\hline 6. Leader Member Exchange & & $-0.482 * *$ & & & & $-0.281 * *$ & & \\
\hline
\end{tabular}


After the correlation and regression analysis, it can be said that leader-member exchange in organic organizational culture affects organizational burnout in higher level and negatively compared to mechanical organizational culture. Therefore, it is observed that our hypothesis is confirmed as a result of the study.

\section{Summary and Tentative Conclusions}

In literature, in other organizational cultures the existence of this relationship has not been questioned, although there are studies related to leader-member exchange affecting burnout. Our findings in this study are higher than the share and participation in the decision of the leaders in the organizational culture of the member states have led to high interest. Therefore, mandating the sharing of leaders in organizational culture, organizational burnout has also been found to be in a declining trend. Especially on behalf of organizational performance leader in organic organizational culture, creating internal groups should be more fair and inclusive. In particular, individual life insurance sales and performance of the services to be focused, the leader in creating internal groups to act selectively blocks. In summary, leader-member exchange in organic organizational culture affects organizational burnout in higher level and negatively compared to mechanical organizational culture.

\section{References}

Albrect, K., (1988), Gerilim Altında Yönetici, Çev: K. Tosun vd., İ.Ü. İşletme Fakültesi, Yayın No.197, İstanbul.

Bauer, T. N. and Green, S. G. (1996), Development of Leader-Member Exchange: A Longitudinal Test, Academy of Management Journal, 39:6, 1538-1567.

Baumgartner, R.J. (2009). "Organizational culture and leadership: Preconditions for the development of a sustainable corporation", Sustainable Development, 17, 102113.

Breland, Jacob W., Treadway, Darren C., Duke, Allison B. ve Adams, Garry L., (2007), "The Interactive Effect of Leader-Member Exchange and Political Skill on Subjective Carrier Success",Journal of Leadership \& Organizational Studies, 13 (3), 1-14.

Cameron, K. S., Quinn, R. E. (1992). Diagnosing and changing organizational culture: Based on the competing values framework, Addison-Wesley, Reading, MA.

Deluga, R. J. and Perry, J.T. (1994), The Role of Subordinate Performance and Ingratiation in Leader-Member Exchanges, Group \& Organization Studies, 19:1, 67-86.

Dipboye, L. R, Howell, C. W. and Smith, S. C. (1994). Understanding Industrial and Organizational Psychology, An Integrated Approach. ABD Harcourt Brace Koleji Yayınları.

Drucker, F. P. (1992). Managing for the Future. Londra: Butterworth / Heinemann.

Dunegan, K. J., Duchon, D. and Uhl-Bien, M. (1992), Examining the Link between Leader-Member Exchange and Subordinate Performance: The Role of Task Analyzability and Variety as Moderators, Journal of Management, 18:1, 59-76. 
Freudenberger, H. J. (1977), Burn-Out: Occupational Hazard of the Child Care Worker, Child Care Quarterly, 6:2, 90-98.

Graen, G.B., Novak, M., \& Sommerkamp, P. (1982). The effects of leader-member exchange and job design on productivity and satisfaction: Testing a dual attachment model. Organizational Behavior and Human Performance, 30, 109131.

Hetland, H., Sandal, G. and Backer, J. (2007), Burnout in the Information Technology Sector: Does Leadership Matter?, European Journal of Work and Organizational Psychology, 16:1, 58-75.

Hofstede, G. (1980). Culture's Consequences: International Differences in Work-related Values, Sage, Beverly Hills, CA.

Jelena V., Milan, N. Olga, H., Edit, T. and Milena N. (2012). Relationship between GLOBE organizational culture dimensions, job satisfaction and leader-member exchange in Serbian organizations. Journal for East European Management Studies. Vol: 17/3.

Kırkbeşoğlu, E. and Tüzün, İ.K., (2009). "Bireycilik - Toplulukçuluk İkileminde Mesleki Özdeşleşme Ve Örgütsel Özdeşleşme Ayrımı". Organizasyon ve Yönetim Bilimleri Dergisi. Sayı: 1/1, ss. $1-8$.

Kostera, M. and Wicha, M. (1996). The Divided Self' of Polish State- owned Enterprises: The Culture of Organizing, Organization Studies, 17 (1): 83-105.

Li, J., Lam, K. and Qian, G. (2001). Does Culture Affect Behavior and Performance of Firms? The Case of Joint Ventures in China, Journal of International Business Studies, 32 (1): 115-131.

Liden, R. C. ve Maslyn M. (1998). Multidimensionality of Leader-Member Exchange: An Empirical Assessment through Scale Development, Journal of Management, Vol.24, No.1, 43-72.

Liden, Robert C. ve Graen, George, (1980), "Generalizability of The Vertical Dyad Linkage Model of Leadership", Academy of management Journal, 23 (3), 451465 .

Maslach, C. (2003). Job burnout: New directions in research and intervention. Current Directions in Psychological Science, 12, 189-192.

Maslach, C. and Jackson, S.E. (1981) The measurement of experienced burnout. Journal of Occupational Behavior 2, 99-113.

Maslach, C., Schaufeli, W. B. and Leiter, M. P. (2001), Job Burnout, Annual Review Psychology, 52 , 397-422.

McCain, A. K. (1994), The Relationship between Head Nurse Leadership Behavior and Staff Nurse Burnout, Phd Thesis, University of Bridgeport, Bridgeport.

Ouchi, W.G. (1987). Teori Z: Japonların Yönetim Tarzı Nasıl İşliyor (Çev. Yakut Güneri), İlgi Yayıncılık, İstanbul.

Pellegrini, E. K. and Scandura, T.A. (2006). Leader-Member Exchange (LMX), Paternalism, and Delegation in The Turkish Business Culture: An Empirical Investigation, Journal of International Business Studies, 37, 264-279. 
Schein, E.H. (1997). "Organizational Culture and Leadership" (2. Ed.), Jossey-Bass, San Francisco.

Seltzer, J. and Numerof, R. E. (1988), Supervisory Leadership and Subordinate Burnout, Academy of Management Journal, 312, 439-446.

Steiner, Dirk D. (1997), Attributions in Leader-Member Exchanges: Implications for Practice, European Journal of Work and Organizational Psychology, 6:1, 59-71.

Talat I., Saif ur Rehman Khan, Ungku N. Ungku Bt. Ahmad, Ishfaq ., (2013) "Organizational learning culture and leader-member exchange quality: The way to enhance organizational commitment and reduce turnover intentions", Learning Organization, The, Vol. 20 Iss: 4/5, pp.322 - 337.

Tziner A, Shultz T, Fisher T. (2008). Justice, leader-member exchange, and job performance: are their relationships mediated by organizational culture? Psychological Reports: Volume 103, Issue , pp. 516-526.

Wayne, S. J., Liden, R. C. and Sparrowe, R. T. (1994), Developing Leader-Member Exchanges the Influence of Gender and Ingratiation, The American Behavioral Scientist, 37:5, 697-714. 